\title{
Sulphur nutrition index in relation to nitrogen uptake and quality of winter wheat grain
}

\author{
Ondrej Sedlár ${ }^{1 *}$, Jirí Balík ${ }^{1}$, Martin Kulhánek ${ }^{1}$, Jindrich Cerny ${ }^{1}$, and Pavel Suran ${ }^{1}$ \\ 'Czech University of Life Sciences Prague, Faculty of Agrobiology, Food and Natural Resources, Kamýcká 129, 16500 Praha-Suchdol, \\ Czech Republic. "Corresponding author (sedlar@af.czu.cz).
}

Received: 15 February 2019; Accepted: 7 May 2019; doi:10.4067/S0718-58392019000300486

\begin{abstract}
A sulphur nutrition index (SNI) is an analogue of the $\mathrm{N}$ nutrition index, which is a widely used simple indicator of plant $\mathrm{N}$ status. The aim of this study was to relate the SNI (ratio of S concentration in shoot biomass to critical S concentration - Sc) to $\mathrm{N}$ uptake, grain yield and breadmaking quality of winter wheat (Triticum aestivum L.) grain during 4-yr small-plot field experiments realized under non-limiting $\mathrm{N}$ conditions in three different locations in the Czech Republic. The model of S dilution curve (Sc) developed by Reussi et al. (2012) for spring wheat was used for expression of the SNI. According to the model, optimal S concentration in shoot biomass was calculated using nothing but shoot biomass weight. The constant value of $\mathrm{Sc}=0.55$ was determined for shoot biomass weight lower than $1.0 \mathrm{tha}^{-1}$. A very strong correlation was recorded between the SNI and an N to S weight ratio (N:S) in shoot biomass. Both, optimal N:S weight ratio in shoot biomass and qualitative parameters of grain (particularly Zeleny sedimentation volume, grain protein content and wet gluten content) were recorded if the SNI exceeded values of 0.80 at the beginning of stem elongation, 0.70 at the late boot stage, and even 0.60 at the beginning of heading despite the fact that the Reussi et al.'s model of S dilution curve was originally applicable only until the end of stem elongation. Correlation between the SNI and relative grain yield was weak.
\end{abstract}

Key words: Critical concentration, dilution curve, gluten, protein content, sulphur status, Triticum aestivum, yield.

\section{INTRODUCTION}

Low content of bioavailable S forms in soils was recorded e.g. in Poland (Siebielec et al., 2017). Concurrently, negative S balance was mentioned by Lozek et al. (2011) in soils in Slovakia. Concurrently, S uptake positively influences both uptake and utilization of N (Salvagiotti et al., 2009). Precise application of S particularly in intensive wheat production systems is then necessary (Flaete et al., 2005). A concurrent management of $\mathrm{N}$ and S is important to reduce potential pollution of residual soil nitrate by increasing $\mathrm{N}$ recovery from the soil while sustaining high $\mathrm{N}$ use efficiency (Salvagiotti et al., 2009).

Critical values for leaf concentrations of total S, sulphate and glutathione change over time and are not suitable for diagnosing $\mathrm{S}$ deficiency early in the growth season. In contrast, an N:S ratio in shoot biomass is a more reliable indicator of plant S status (Blake-Kalff et al., 2000). Optimal values of the $\mathrm{N}: \mathrm{S}$ ratio in shoot biomass were expressed for various growth stages of wheat by many authors: after 6 wk of growth (Qian and Schoenau, 2007), during tillering (Reussi et al., 2011), during stem elongation (Calvo et al., 2008), during ear emergence (Steinfurth et al., 2012), and particularly in grain (Zhao et al., 1999; Tea et al., 2007).

However, one of the problems using the $\mathrm{N}: \mathrm{S}$ ratio is that a surplus of one of these elements may be interpreted as a deficiency of the other one (Scherer, 2001). Furthermore, determination of the N:S ratio requires two precise analytical measurements (Blake-Kalff et al., 2000). Hence, Reussi et al. (2012) expressed S dilution critical curve from the beginning of tillering to the end of stem elongation of spring wheat. This model takes account of decreasing plant $\mathrm{S}$ concentration during wheat growth because the optimal S concentration in shoot biomass is calculated using nothing but shoot biomass 
weight (Reussi et al., 2012). The calculation of S dilution critical curve enables to express the S nutrition index (SNI) analogous to the $\mathrm{N}$ nutrition index (NNI), which is widely used for quantifying the $\mathrm{N}$ status (Sadras and Lemaire, 2014). Sulphur nutrition index is calculated as a ratio of measured $\mathrm{S}$ content in shoot biomass and the critical $\mathrm{S}$ concentration calculated from the model of S dilution critical curve. For SNI > 1 the crop S status can be considered as non-limiting, and for SNI < 1 the crop S status can be considered as limited by S supply. On the other hand, the model according to Reussi et al. (2012) of S dilution critical curve is relevant to weight of shoot biomass higher than $1.0 \mathrm{t} \mathrm{DM} \mathrm{ha-1}$, which is a problem for $\mathrm{S}$ status determination at earlier growth stages.

The aim of this study was to answer the following questions: Can SNI be considered as an appropriate indicator of winter wheat S status under Central European field conditions? Does the value of SNI = 1 lead to the highest grain yield and the best quality of winter wheat grain? Is it possible to use the $\mathrm{S}$ dilution critical curve for earlier or later growth stages of winter wheat than the model according to Reussi et al. (2012) states?

\section{MATERIAL AND METHODS}

Small-plot field experiments with winter wheat (Triticum aestivum L.) 'Sulamit' were realized during a 4-yr period (20072010) at three locations with different soil-climatic conditions in the Czech Republic (Central Europe): Hněvčeves (L1; $50^{\circ} 18^{\prime} \mathrm{N}, 15^{\circ} 42^{\prime} \mathrm{E}, 265 \mathrm{~m}$ a.s.1., Haplic Luvisol (FAO classification), average precipitations and temperature - $560 \mathrm{~mm}$, $8.4^{\circ} \mathrm{C}, \mathrm{pH}\left(\mathrm{CaCl}_{2}\right) 6.3$, available nutrient contents (Mehlich 3): $89 \mathrm{mg} \mathrm{P} \mathrm{kg}^{-1}, 292 \mathrm{mg} \mathrm{K} \mathrm{kg}^{-1}, 158 \mathrm{mg} \mathrm{Mg} \mathrm{kg}{ }^{-1}, 2350 \mathrm{mg} \mathrm{Ca}$ $\mathrm{kg}^{-1}$ ), Humpolec (L2; 49 $32^{\prime} \mathrm{N}, 15^{\circ} 21^{\prime}$ E, $525 \mathrm{~m}$ a.s.1., Gleic Cambisol, average precipitations and temperature - $678 \mathrm{~mm}$, $6.7^{\circ} \mathrm{C}, \mathrm{pH}\left(\mathrm{CaCl}_{2}\right) 6.1$, available nutrient contents (Mehlich 3): $90 \mathrm{mg} \mathrm{P} \mathrm{kg}{ }^{-1}, 193 \mathrm{mg} \mathrm{K} \mathrm{kg}{ }^{-1}, 183 \mathrm{mg} \mathrm{Mg} \mathrm{kg}{ }^{-1}, 2250 \mathrm{mg}$ $\mathrm{Ca} \mathrm{kg}^{-1}$ ) and Ivanovice na Hané (L3; 49 $18^{\prime} \mathrm{N}, 17^{\circ} 5^{\prime} \mathrm{E}, 225 \mathrm{~m}$ a.s.l., Chernozem, average precipitations and temperature - $554 \mathrm{~mm}, 9.3^{\circ} \mathrm{C}, \mathrm{pH}\left(\mathrm{CaCl}_{2}\right) 7.3$, available nutrient contents (Mehlich 3): $137 \mathrm{mg} \mathrm{P} \mathrm{kg}^{-1}, 390 \mathrm{mg} \mathrm{K} \mathrm{kg}{ }^{-1}, 245 \mathrm{mg} \mathrm{Mg} \mathrm{kg}^{-1}$, $4458 \mathrm{mg} \mathrm{Ca} \mathrm{kg}^{-1}$ ). Water soluble $\mathrm{S}$ varied among years, average contents were: $12.3 \mathrm{mg} \mathrm{kg}^{-1}$ for L1, $15.1 \mathrm{mg} \mathrm{kg}^{-1}$ for L2, and $8.2 \mathrm{mg} \mathrm{kg}^{-1}$ for $\mathrm{L} 3$.

The sowing density was 450 seeds $\mathrm{m}^{-2}$, the size of each plot was $39 \mathrm{~m}^{2}$, of which $15 \mathrm{~m}^{2}$ were harvested by a small-plot combine harvester; grain yield was determined by weighing grains from individual plots and the result was converted to $0 \%$ moisture. Samples of shoot biomass at the BBCH 30 growth stage (beginning of stem elongation), BBCH 45 growth stage (late boot stage) and BBCH 51 (beginning of heading) were taken from a $0.25 \mathrm{~m}^{2}$ area. The $\mathrm{N}: \mathrm{S}$ ratio was determined using the weight concentrations expressed in $\mathrm{g} \mathrm{kg}^{-1}$ of $\mathrm{N}$ and $\mathrm{S}$ in shoot biomass according to Blake-Kalff et al. (2000).

Levels of $150 \mathrm{~kg} \mathrm{~N} \mathrm{ha}^{-1}, 200 \mathrm{~kg} \mathrm{~N}^{-1}$ and $150 \mathrm{~kg} \mathrm{~N} \mathrm{ha}^{-1}+40 \mathrm{~kg} \mathrm{~S} \mathrm{ha}^{-1}$, respectively, were applied in mineral fertilizers using two techniques of fertilizers application: topdressing in three split $\mathrm{N}$ doses on the soil surface during spring vegetation and $\mathrm{N}$ fertilizers injection into soil at the beginning of spring vegetation, respectively. Each treatment had four replicates. Detailed characteristics of the experimental scheme are given by Sedlar et al. (2015).

Plant $\mathrm{N}$ status was assessed by critical $\mathrm{N}$ concentration $\left(\mathrm{N}_{\mathrm{c}}\right)$ expressed by Justes et al. (1994). Nitrogen nutrition index (NNI) was calculated as a ratio of measured shoot total $\mathrm{N}$ concentration $(\%)$ and $\mathrm{N}_{\mathrm{c}}$ (Sadras and Lemaire, 2014). To reduce the influence of $\mathrm{N}$ status on evaluation of $\mathrm{S}$ uptake, only plant samples with optimal range of $\mathrm{N}$ concentration in shoot biomass were included in our results, i.e. samples with NNI $=0.90-1.10$ at the BBCH 30 and BBCH 45 growth stages and $\mathrm{NNI}=0.85-1.15$ at the $\mathrm{BBCH} 51$ growth stage.

Total $\mathrm{N}$ concentration in shoot biomass was determined by the Kjeldahl method using the Vapodest 50s (C. Gerhardt, Königswinter, Germany). Grain protein content was expressed as $\mathrm{N} \times 5.7$. Sulphur content in shoot biomass was determined using with optical emission spectroscopy with inductively coupled plasma (ICP-OES Agilent 720; Agilent Technologies, Santa Clara, California, USA). Zeleny sedimentation volume and a wet gluten content in DM of grain were determined using the NIR OmegAnalyzer G (Bruins Instrument, Salem, Massachusetts, USA). Due to a significant effect of location on the previously mentioned variables, all variables were expressed as relative values related to the averages of individual locations (Table 1).

Critical S concentration $\left(S_{c}\right)$ in shoot biomass was calculated according to Reussi et al. (2012):

$$
S_{c}=0.37 \mathrm{DM}^{-0.169}
$$

where $\mathrm{DM}$ is shoot DM $\left(\mathrm{t} \mathrm{ha}^{-1}\right)$. Based on our results, the constant value $S_{c}=0.55$ was used for $\mathrm{DM}<1.0 \mathrm{t} \mathrm{ha}^{-1}$ (see Results and Discussion). 
Table 1. Average values of variables at individual experimental locations (L1-L3) across all experimental years.

\begin{tabular}{lccllc}
\hline Location & TGW & $\begin{array}{c}\text { Zeleny sedimentation } \\
\text { volume }\end{array}$ & GPC & WGC & $\begin{array}{c}\text { Grain } \\
\text { yield }\end{array}$ \\
\hline & $\mathrm{g}$ & $\mathrm{mL}$ & - & & \\
$\mathrm{L} 1$ & $47.8 \mathrm{c}$ & $45.7 \mathrm{~b}$ & $13.0 \mathrm{a}$ & $26.5 \mathrm{a}$ & $11.10 \mathrm{a}$ \\
$\mathrm{L} 2$ & $40.2 \mathrm{a}$ & $52.2 \mathrm{a}$ & $12.9 \mathrm{a}$ & $24.9 \mathrm{~b}$ & $7.20 \mathrm{~b}$ \\
$\mathrm{~L} 3$ & $44.5 \mathrm{~b}$ & $52.8 \mathrm{a}$ & $13.8 \mathrm{~b}$ & $28.8 \mathrm{c}$ & $8.93 \mathrm{c}$ \\
\hline
\end{tabular}

Values within the column marked with the same letter are nonsignificantly different according Tukey test $(\mathrm{p} \leq 0.05)$.

TGW: Thousand grain weight; GPC: grain protein content; WGC: wet gluten content.

The SNI was calculated analogously to NNI expressed by Sadras and Lemaire (2014):

$$
S N I=S_{m} / S_{c}
$$

where $S_{m}$ is total S content measured in shoot biomass (\%) and $S_{c}$ is a critical S concentration calculated from the model of S dilution critical curve (Reussi et al., 2012).

Linear regression and logarithmic regression were used for calculation of correlations among studied variables. A statistical analysis of data was carried out using Statistica 13 (TIBCO Software Inc., Palo Alto, California, USA). A standard ANOVA with the Tukey test was used to evaluate differences of variables among individual experimental locations.

\section{RESULTS AND DISCUSSION}

\section{Critical $S$ concentration for low shoot biomass}

The calculation of critical S concentration for shoot DM weight lower than $1.0 \mathrm{t} \mathrm{ha}^{-1}$ has not been defined by the model of S dilution critical curve $\left(S_{c}\right)$ expressed by Reussi et al. (2012). However, in our experiments, 58\% of all plant samples achieved lower weight of shoot DM than $1.0 \mathrm{t} \mathrm{ha}^{-1}$ at the BBCH 30 growth stage indicating a need for definition of the critical S concentration for low shoot biomass. For the calculation of the NNI, Justes et al. (1994) and Yue et al. (2012) expressed a $\mathrm{N}_{\mathrm{c}}$ for low shoot biomass by a constant value calculated as an average $\mathrm{N}$ concentration in shoot biomass of non-limiting $\mathrm{N}$ treatments.

Based on our results, the constant value of the critical $\mathrm{S}$ concentration for low shoot biomass was taken to be $\mathrm{S}_{\mathrm{c}}=$ 0.55 . The value of 0.55 is an average $S$ concentration in shoot biomass when shoot DM did not exceed $1.0 \mathrm{t} \mathrm{ha}^{-1}$ under non-limiting $\mathrm{S}$ conditions (data not shown). In that case, wheat plants had a N:S ratio in shoot biomass lower than 14.9:1 (median 7.32:1) at the $\mathrm{BBCH} 30$ growth stage which was optimal for the highest grain yields of wheat according to the results of Blake-Kalff et al. (2000). To reduce the influence of plant $\mathrm{N}$ status on evaluation of S uptake, only plant samples with optimal $\mathrm{N}$ concentration in shoot biomass were included in our results, i.e. samples with values of NNI $=0.95-1.05$ (0.99 median). On top of that, only plants with sufficient $\mathrm{S}$ content in grain i.e. grain $\mathrm{N}: \mathrm{S}=11-15: 1$ (median 12.6:1) (Tea et al., 2007) and simultaneously with sufficient $\mathrm{S}$ content in straw, i.e. straw N:S = 3-7 (4.79 median) (Steinfurth et al., 2012) were evaluated. The average $S$ concentration was calculated out of 20 cases in total.

\section{SNI at the BBCH 30 and 45 growth stages}

Figure 1 describes a very strong correlation between the SNI at the BBCH 30 growth stage and the N:S ratio in shoot biomass at the $\mathrm{BBCH} 30$ growth stage. After substituting the $\mathrm{x}$-value in regression equation (Figure 1) for the upper limit of the optimal N:S ratio stated by Blake-Kalff et al. (2000), i.e. N:S $=14.9$, SNI was equivalent to the value of SNI $=0.73$ at the $\mathrm{BBCH} 30$ growth stage.

The correlation between the SNI at the BBCH 45 growth stage and the N:S ratio in shoot biomass at the BBCH 45 growth stage was also very strong. After substituting the $\mathrm{x}$-value in regression equation (Figure 2) for the N:S ratio determined by Calvo et al. (2008) at the BBCH 37 growth stage after the highest S supply, i.e. N:S = 11-13, SNI was equivalent to values of $0.84-0.72$ at the $\mathrm{BBCH} 45$ growth stage.

According to the findings of Hrivna et al. (2015) and Klikocka et al. (2016), S fertilization improves wheat grain yield, grain specific weight, protein content, gluten content and Zeleny sedimentation volume. Therefore, linear regressions 
Figure 1. Correlation between the sulphur nutrition index at the $\mathrm{BBCH} 30$ growth stage and the $\mathrm{N}: \mathrm{S}$ ratio in shoot biomass at the BBCH 30 growth stage using the constant value of critical $S$ concentration $\left[S_{c}\right]=0.55$ for shoot $D M<1 \mathrm{t}$ $h^{-1}$ under non-limiting $N$ conditions $(\mathrm{N}$ nutrition index $=0.90-1.10)$. The number of cases was 138.



Figure 2. Correlation between the sulphur nutrition index at the $\mathrm{BBCH} 45$ growth stage and the $\mathrm{N}: \mathrm{S}$ ratio in shoot biomass at the BBCH 45 growth stage under non-limiting $N$ conditions ( $N$ nutrition index $=0.90-1.10$ ). The number of cases was 74 .



describing correlations between the SNIs (y-values) at the BBCH 30 and BBCH 45 growth stages and both quantity and quality of winter wheat grain (x-values) are given in Table 2. The strongest correlation was recorded between the SNI at the $\mathrm{BBCH} 30$ growth stage and relative Zeleny sedimentation volume in which case the correlation was moderate. The other variables correlated with the SNI at the BBCH 30 growth stage only weakly. To express the optimal values of the $\mathrm{SNI}$, the $\mathrm{x}$-value in regression equation was substituted for a value of 1 which is an average of studied relative variables. In that case, SNI achieved a value of 0.85 for average Zeleny sedimentation index. In case of SNI $>0.88$, all studied relative parameters reached above-average values. With respect to grain quality of winter wheat, the SNI should be higher than the results suggest from correlation between the SNI at the $\mathrm{BBCH} 30$ growth stage and the N:S ratio in shoot biomass at the $\mathrm{BBCH} 30$ growth stage. On the other hand, only very weak correlations were recorded between the SNI at the BBCH 45 growth stage and studied relative variables (Table 2).

Table 2. Relations between relative both quantitative and qualitative parameters of winter wheat grain ( $x$-values) and the sulphur nutrition index (SNI) (y-value) at the BBCH 30 (using the constant value of critical $S$ concentration $\left[\mathrm{S}_{\mathrm{c}}\right]=0.55$ for shoot $\mathrm{DM}<1 \mathrm{t} \mathrm{ha}^{-1}$ ) and $\mathrm{BBCH} 45$ growth stage, respectively.

\begin{tabular}{|c|c|c|c|c|c|c|}
\hline \multirow[b]{2}{*}{$\begin{array}{l}\text { Relative } \\
\text { parameter (x) }\end{array}$} & \multicolumn{3}{|c|}{ SNI $30(y)$} & \multicolumn{3}{|c|}{ SNI $45(y)$} \\
\hline & $\begin{array}{l}\text { Linear regression } \\
\text { equation }\end{array}$ & $\mathrm{R}^{2}$ & $\begin{array}{l}\text { SNI-value } \\
\text { if } x=1\end{array}$ & $\begin{array}{l}\text { Linear regression } \\
\text { equation }\end{array}$ & $\mathrm{R}^{2}$ & $\begin{array}{l}\text { SNI-value } \\
\text { if } x=1\end{array}$ \\
\hline TGW & $y=1.1338 x-0.2489$ & $0.111 * * *$ & 0.88 & $y=0.0228 x+0.6622$ & 0.000 & 0.69 \\
\hline Zeleny SV & $y=0.6919 x+0.1563$ & $0.273 * * *$ & 0.85 & $y=-0.0912 x+0.7599$ & 0.003 & 0.67 \\
\hline GPC & $y=0.5941 x-0.0252$ & $0.051 *$ & 0.87 & $y=-0.8242 x+1.5042$ & 0.032 & 0.68 \\
\hline WGC & $y=0.766 x+0.1033$ & $0.095 * * *$ & 0.87 & $y=-0.0644 x+0.7355$ & 0.001 & 0.67 \\
\hline Grain yield & $y=0.5018 x+0.3726$ & 0.015 & 0.87 & $y=-0.06255 x+1.2887$ & 0.032 & 0.66 \\
\hline
\end{tabular}

$*, * *, * * *$ Significant at the $0.05,0.01$, and 0.001 probability levels, respectively.

TGW: Thousand grain weight; Zeleny SV: Zeleny sedimentation volume; GPC: grain protein content; WGC: wet gluten content. 


\section{SNI at the beginning of heading}

According to the results of Reussi et al. (2012), the model of S dilution curve was originally applicable only to the end of stem elongation of wheat. However, a very strong correlation was found between the SNI at the BBCH 51 growth stage and an N:S ratio in shoot biomass at the BBCH 51 growth stage (Figure 3). After substituting the $\mathrm{x}$-value in regression equation (Figure 3) for the N:S ratio in shoot biomass stated by Steinfurth et al. (2012) as the optimum for the ear emergence growth stage, i.e. $\mathrm{N}: \mathrm{S}=13-14$, SNI was equivalent to values of 0.64-0.59 at the BBCH 51 growth stage.

Moderate correlation was recorded between the SNI at the $\mathrm{BBCH} 51$ growth stage and a relative Zeleny sedimentation volume and relative wet gluten content (Table 3). After substituting the $\mathrm{x}$-value in regression equation (Table 3 ) for an average value of variable, i.e. $\mathrm{x}=1$, the SNI corresponded to values of SNI $=0.61$ and $\mathrm{SNI}=0.60$, respectively. These values comply with the optimal SNI values, i.e. $\mathrm{SNI}=0.64-0.59$, derived from the relation between the SNI and the N:S ratio in shoot biomass for the BBCH 51 growth stage (Figure 3).

Table 3. Relations between relative both quantitative and qualitative parameters of winter wheat grain ( $x$-values) and the sulphur nutrition index (SNI) (y-value) determined at the BBCH 51 growth stage.

\begin{tabular}{lclc}
\hline Relative parameter $(\mathrm{x})$ & Linear regression equation & \multicolumn{1}{c}{$\mathrm{R}^{2}$} & SNI-value if $\mathrm{x}=1$ \\
\hline TGW & $\mathrm{y}=1.0357 \mathrm{x}-0.4337$ & 0.029 & 0.60 \\
Zeleny SV & $\mathrm{y}=0.6511 \mathrm{x}-0.0380$ & $0.196^{* * *}$ & 0.61 \\
GPC & $\mathrm{y}=0.9152 \mathrm{x}-0.3171$ & $0.062^{*}$ & 0.60 \\
WGC & $\mathrm{y}=1.0097 \mathrm{x}-0.4094$ & $0.158^{* * *}$ & 0.60 \\
Grain yield & $\mathrm{y}=0.6295 \mathrm{x}-0.0401$ & $0.070^{*}$ & 0.59 \\
\hline
\end{tabular}

$*, * *, * * *$ Significant at the $0.05,0.01$, and 0.001 probability levels, respectively. TGW: Thousand grain weight; Zeleny SV: Zeleny sedimentation volume; GPC: grain protein content; WGC: wet gluten content.

Figure 3. Correlation between the sulphur nutrition index at the BBCH 51 growth stage and the N:S ratio in shoot biomass at the BBCH 51 growth stage under non-limiting $N$ conditions ( $N$ nutrition index $=0.85-1.15$ ). The number of cases was 66.

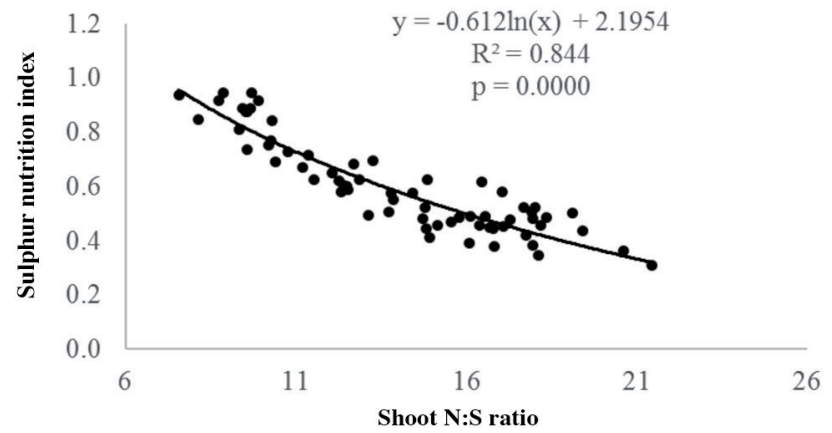

The SNI at the BBCH 51 can be utilizable with respect to late S fertilization because Steinfurth et al. (2012) state that S fertilization at ear emergence growth stage prevents S deficiency in late stages of wheat growth. Zorb et al. (2009) state that the late $\mathrm{S}$ fertilization was found to improve the composition of gluten proteins and baking quality of winter wheat grain.

The fact that a nutrition index equal to 1 may not be always optimal for yield and quality of harvested products was also shown in case of NNI of various crops (Debaeke et al., 2012; Hu et al., 2014; Sedlar et al., 2017).

The SNI only weakly correlated with relative grain yield of winter wheat. Klikocka et al. (2016) also recorded higher effect of S fertilization on grain quality of wheat rather than on grain yield. According to the results of Kulhanek et al. (2014), nonsignificant effect of S fertilization on grain yield of winter wheat was also found under field conditions of the Czech Republic. 


\section{CONCLUSIONS}

Calculation of the S nutrition index (SNI) using the model of Reussi et al. (2012) of S dilution curve was proved to be a reliable indicator of winter wheat $\mathrm{S}$ nutrition status even at the beginning of heading (BBCH 51). Calculation of the SNI was feasible also at the beginning of spring vegetation when shoot dry biomass weight was lower than $1.0 \mathrm{t} \mathrm{ha}^{-1}$. In that case, the constant value of the critical S concentration in shoot biomass 0.55 was determined. Both optimal N:S weight ratio in shoot biomass and qualitative parameters of grain (particularly Zeleny sedimentation volume, grain protein content and wet gluten content) were recorded if the SNI exceeded values of 0.80 at the beginning of stem elongation (BBCH 31), 0.70 at the late boot stage (BBCH 45) and 0.60 at the beginning of heading (BBCH 51). Correlation between the SNI and relative grain yield was weak.

\section{ACKNOWLEDGEMENTS}

This study was supported by the TAČR agency within project nr TJ01000454.

\section{REFERENCES}

Blake-Kalff, M.M.A., Hawkesford, M.J., Zhao, F.J., and McGrath, S.P. 2000. Diagnosing sulfur deficiency in field-grown oilseed rape (Brassica napus L.) and wheat (Triticum aestivum L.) Plant and Soil 225:95-107.

Calvo, N.I.R., Echeverria, H.E., and Rozas, H.S. 2008. Usefulness of foliar nitrogen-sulfur ratio in spring red wheat. Journal of Plant Nutrition 31:1612-1623.

Debaeke, P., van Oosterom, E.J., Justes, E., Champolivier, L., Merrien, A., Aguirrezabal, L.A.N., et al. 2012. A species-specific critical nitrogen dilution curve for sunflower (Helianthus annuus L.) Field Crops Research 136:76-84.

Flaete, N.E.S., Hollung, K., Ruud, L., Sogn, T., Faergestad, E.M., Skarpeid, H.J., et al. 2005. Combined nitrogen and sulphur fertilisation and its effect on wheat quality and protein composition measured by SE-FPLC and proteomics. Journal of Cereal Science 41:357-369.

Hrivna, L., Kotkova, B., and Buresova, I. 2015. Effect of sulphur fertilization on yield and quality of wheat grain. Cereal Research Communications 43:344-352.

Hu, D.W., Sun, Z.P., Li, T.L., Yan, H.Z., and Zhang, H. 2014. Nitrogen nutrition index and its relationship with n use efficiency, tuber yield, radiation use efficiency, and leaf parameters in potatoes. Journal of Integrative Agriculture 13:1008-1016.

Justes, E., Mary, B., Meynard, J.M., Machet, J.M., and Thelierhuche, L. 1994. Determination of a critical nitrogen dilution curve for winter-wheat crops. Annals of Botany 74:397-407.

Klikocka, H., Cybulska, M., Barczak, B., Narolski, B., Szostak, B., Kobialka, A., et al. 2016. The effect of sulphur and nitrogen fertilization on grain yield and technological quality of spring wheat. Plant, Soil and Environment 62:230-236.

Kulhanek, M., Balik, J., Cerny, J., Peklova, L., and Sedlar, O. 2014. Winter wheat fertilizing using nitrogen-sulphur fertilizer. Archives of Agronomy and Soil Science 60:67-74.

Lozek, O., Slamka, P., Kajanovicova, I., and Hankova, H. 2011. Balance of sulphur and application of fertilizers with sulphur in Slovakia. p. 61-66. In Reasonable use of fertilizers. Czech University of Life Sciences, Prague, Czech Republic. (In Slovak).

Qian, P., and Schoenau, J.J. 2007. Using an anion exchange membrane to predict soil available N and S supplies and the impact of $\mathrm{N}$ and $\mathrm{S}$ fertilization on canola and wheat growth. Pedosphere 17:77-83.

Reussi, N., Echeverria, H., and Rozas, H.S. 2011. Diagnosing sulfur deficiency in spring red wheat: Plant analysis. Journal of Plant Nutrition 34:573-589.

Reussi, N., Echeverria, H.E., and Rozas, H.S. 2012. Stability of foliar nitrogen:sulfur ratio in spring red wheat and sulfur dilution curve. Journal of Plant Nutrition 35:990-1003.

Sadras, V.O., and Lemaire, G. 2014. Quantifying crop nitrogen status for comparisons of agronomic practices and genotypes. Field Crops Research 164:54-64.

Salvagiotti, F., Castellarin, J.M., Miralles, D.J., and Pedrol, H.M. 2009. Sulfur fertilization improves nitrogen use efficiency in wheat by increasing nitrogen uptake. Field Crops Research 113:170-177.

Scherer, H.W. 2001. Sulphur in crop production - invited paper. European Journal of Agronomy 14:81-111.

Sedlar, O., Balik, J., Cerny, J., Kulhanek, M., and Vasak, F. 2017. Relation between nitrogen nutrition index and production of spring malting barley. International Journal of Plant Production 11:379-388.

Sedlar, O., Balik, J., Cerny, J., Peklova, L., and Kulhanek, M. 2015. Nitrogen uptake by winter wheat (Triticum aestivum L.) depending on fertilizer application. Cereal Research Communications 43:515-524. 
Siebielec, G., Smreczak, B., Klimkowicz-Pawlas, A., Kowalik, M., Kaczynski, R., Koza, P., et al. 2017. Report on the third stage for completion of the order "Monitoring of chemism of arable soils in Poland in the years 2015-2017. Pulawy, Poland. Available at http://www.gios.gov.pl/images/dokumenty/pms/monitoring_jakosci_gleb/Raport_MChG_etap3.pdf (accessed May 2019). (In Polish).

Steinfurth, D., Zorb, C., Braukmann, F., and Muhling, K.H. 2012. Time-dependent distribution of sulphur, sulphate and glutathione in wheat tissues and grain as affected by three sulphur fertilization levels and late S fertilization. Journal of Plant Physiology 169:72-77.

Tea, I., Genter, T., Naulet, N., Marie, L.M., and Kleiber, D. 2007. Interaction between nitrogen and sulfur by foliar application and its effects on flour bread-making quality. Journal of the Science of Food and Agriculture 87:2853-2859.

Yue, S.C., Meng, Q.F., Zhao, R.F., Li, F., Chen, X.P., Zhang, F.S., et al. 2012. Critical nitrogen dilution curve for optimizing nitrogen management of winter wheat production in the North China Plain. Agronomy Journal 104:523-529.

Zhao, F.J., Salmon, S.E., Withers, P.J.A., Monaghan, J.M., Evans, E.J., Shewry, P.R., et al. 1999. Variation in the breadmaking quality and rheological properties of wheat in relation to sulphur nutrition under field conditions. Journal of Cereal Science 30:19-31.

Zorb, C., Steinfurth, D., Seling, S., Langenkamper, G., Koehler, P., Wieser, H., et al. 2009. Quantitative protein composition and baking quality of winter wheat as affected by late sulfur fertilization. Journal of Agricultural and Food Chemistry 57:3877-3885. 